\title{
Crossing the next frontier: The role of ICT in driving the financialization of credit
}

\section{Journal Article}

\section{Author(s):}

Drummer, Daniel; Feuerriegel, Stefan; Neumann, Dirk

Publication date:

2017-09

Permanent link:

https://doi.org/10.3929/ethz-b-000182389

Rights / license:

In Copyright - Non-Commercial Use Permitted

Originally published in:

Journal of Information Technology 32(3), https://doi.org/10.1057/s41265-017-0035-9 


\title{
Crossing the next frontier: The role of ICT in driving the financialization of credit
}

\begin{abstract}
Financialization describes a phenomenon whereby financial markets assume an increasingly dominant role within the economy. This paper seeks to dissect the role of information and communications technology (ICT) in financialization by following a cross-disciplinary approach across finance, economics and information systems. Accordingly, we develop a general framework describing the relationship between ICT and financialization. This framework allows us to investigate the recent rise of online marketplaces for credit. Consequently, ICT is not only facilitating, but fundamentally driving a disintermediation of banks through advances in computing, communication and information technology. We also provide supporting evidence from interviews with almost 40 senior experts and C-level executives. Interestingly, only rather recent innovations have enabled the popularity of marketplace lending, such as cloud computing, big data, scalable IT infrastructures and comprehensive ecosystems of programming interfaces. In contrast, we observe a slow integration of advanced analytics in the field of risk management. Based on our analysis, the paper also discusses cross-country implications for marketplace lending, financialization and regulation.
\end{abstract}

Keywords: financialization; information technology; marketplace lending; peer-to-peer lending; credit; intermediation

This is a post-peer-review, pre-copyedit version of an article published in Journal of Information Technology (JIT). The definitive publisher-authenticated version

Drummer, Daniel, Stefan Feuerriegel, and Dirk Neumann. "Crossing the next frontier: the role of ICT in driving the financialization of credit." Journal of Information Technology 32.3 (2017): 218-233, DOI: $10.1057 / \mathrm{s} 41265-017-0035-9$

is available online at: http://link.springer.com/article/10.1057/s41265-017-0035-9

\section{Introduction}

The term financialization was coined by economists in the early 2000 s to reflect the surging dominance of financial markets with regard to the economy. As such, financialization refers to "the increasing role of financial motives, financial markets, financial actors and financial institutions in the operation of the domestic and international economies" (Epstein, 2005, p. 3). 
The emergence of financialization triggered an unprecedented shift from industrial to financial capitalism. Its consequences go beyond pure macroeconomic effects (Epstein, 2005; Palley, 2013), but also entail developments in a variety of different dimensions, including real sector changes (Lagoarde-Segot, 2016), growth in household indebtedness (Jordá et al., 2016; Kim, 2013) and societal changes (van der Zwan, 2014).

We illustrate the extent of financialization among these categories, which we group by their scope - namely, macroeconomics, corporations/institutions and asset classes.

(a) On a macroeconomic level, financialization compares quantitative figures from the financial sector, such as profits, to the total economy. For instance, the proportional profits of the financial industry in the U.S. increased steadily from roughly $20 \%$ in 1980 to more than $40 \%$ by 2000 (Krippner, 2005).

(b) Financialization also takes place on a corporate or institutional level. This is reflected by the share of profits from financial activities earned by non-financial firms (Krippner, 2005). The profits can have different origins, such as leasing or capital market transactions by non-financial firms. In the U.S., the ratio rose from just above $12 \%$ in 1948 to a peak of $53 \%$ in 2001 (Stockhammer, 2010).

(c) Financialization with regard to assets compares market capitalization or trading volumes of a specific asset class in relation to other variables. For example, the capitalization of the U.S. stock market expanded from $58 \%$ of the gross domestic product (GDP) in 1988 to $163 \%$ in 1999 (Stockhammer, 2010).

Altogether, the previous statistics highlight the growing relevance of financial markets as characterized by financialization.

In this paper, we focus foremost on the third class, which views financialization in the light of asset classes. Trading of assets has been experiencing a veritable eruption. Historically, access to assets was limited to floor-based stock brokers, who acted as intermediaries between investors and companies. However, the rise of electronic trading disrupted the broker business and enabled direct access to assets (Parker and Weber, 2014; Weber, 2006). Table 1 shows the access to markets for different liquid assets in 2005 as an instantiation of financialization. Back then, retail 
and institutional investors were able to - either directly or indirectly - invest into corporate equities (i.e. stocks), for instance, through mutual funds. Similarly, investments in commodities were possible via futures (but such transactions confined to sophisticated investors). Furthermore, investors could purchase real estate directly, with the disadvantage of high transaction costs, whereas real estate investment trusts enabled indirect investments.

In contrast to assets, opportunities for direct and securitized investments in credit liabilities remained scarce until the year 2005, as Table 1 shows. However, in the mid 2000s, financialization expanded its reach into the giant credit market, that has long been ripe for a sea change. While banks have maintained a quasi-monopoly on issuing credit in the past, this is about to change with the advent of marketplace lending, which aims at directly connecting credit demand and investors. For the first time, retail investors can now invest electronically in consumer credit as an asset class, while online marketplaces fulfill a function that had traditionally been reserved for banks. Based on public figures, a market of more than USD 15 trillion has - in principle now been unlocked for financial investors.

\begin{tabular}{|c|c|c|c|c|c|}
\hline \multirow[t]{2}{*}{ Asset } & \multicolumn{2}{|c|}{$\begin{array}{c}\text { Direct access } \\
\text { (electronic trading) }\end{array}$} & \multicolumn{2}{|c|}{$\begin{array}{l}\text { Securitized access } \\
\text { (portfolio level) }\end{array}$} & \\
\hline & Retail & Institutional & Retail & Institutional & \\
\hline \multicolumn{6}{|l|}{ Liquid assets } \\
\hline Corporate equities & $\checkmark$ & $\checkmark$ & & & \\
\hline Corporate bonds & $\checkmark$ & $\checkmark$ & & & \\
\hline Commodities (futures) & $x$ & $\checkmark$ & & & \\
\hline Real estate & $x$ & $x$ & $(\checkmark)$ & $\checkmark$ & \\
\hline \multicolumn{6}{|l|}{ Credit liabilities } \\
\hline Syndicated loans & $x$ & $x$ & $x$ & $\checkmark$ & \multirow{6}{*}{$\begin{array}{l}\text { Marketplace lending } \\
\text { has recently enabled } \\
\text { direct access }\end{array}$} \\
\hline Mortgage loans & $x$ & $x$ & $x$ & $\checkmark$ & \\
\hline Small business loans & $x$ & $x$ & $x$ & $\checkmark$ & \\
\hline Consumer loans & $x$ & $x$ & $x$ & $\checkmark$ & \\
\hline Trade receivables & $x$ & $x$ & $x$ & $\checkmark$ & \\
\hline Student loans & $x$ & $x$ & $x$ & $\checkmark$ & \\
\hline
\end{tabular}

Table 1. Check marks indicate access to credit as an investment class in the year 2005, when access was still severely restricted.

Previous research sometimes refers to marketplace lending as peer-to-peer or P2P lending. Initially, this term was more common, as it reflected the notion of connecting private individ- 
uals directly. However, institutional investors increasingly engage in marketplace lending and, nowadays, the term "marketplace lending", is more common among practitioners. Hence, we maintain a consistent naming convention by using the term "marketplace lending".

While financialization has been in the spotlight of academics lately, knowledge of how information and communications technology (ICT) drives financialization has received surprisingly little attention. As a remedy, this paper contributes to the general body of knowledge by studying the role of ICT in financialization. We particularly address how ICT has enabled financial actors to invest directly in household credit for the first time. Our findings show that the financialization of credit resembles earlier phases of financialization - namely, the the electronification of equity markets in the 1990s.

As an effect of the electronification of stock trading, ICT has disrupted the floor-based broker model and disintermediated access to equity. To dissect this shift, we develop a comprehensive framework for studying financialization and set out to study ICT drivers in marketplace lending. We enrich our explanations with insights from almost 40 interviews with high-profile experts and C-level executives from the financial industry, the financial technology (i. e. FinTech) sector and marketplace lending. The appendix provides a detailed list of all interview partners and describes our selection procedure. Consequently, our paper identifies marketplace lending as an area where ICT is expected to significantly fuel financialization now and in the near future.

The remainder of this paper is organized as follows. The next section develops a framework classifying the key enablers (including ICT) of electronic stock trading. Subsequently, we adapt the framework to marketplace lending and identify ICT as the key factor for driving a new wave of financialization in marketplace lending. We afterwards discuss this finding using almost 40 expert interviews and derive cross-country implications regarding regulation, financialization and marketplace lending. The last section concludes with a summary.

\section{ICT and the financialization of stock trading}

We now describe the influence of ICT on the electronification of stock trading. For this purpose, this section presents a comprehensive framework for the financial industry that helps to 
unravel the drivers of financialization (see Figure 2). Our comments in this section provide a thorough explanation of each item. We organized the structure similarly to the structure-conductperformance paradigm from industrial organization (Bain, 1968). Our treatment is also consistent with transaction cost theory.

The market for stock trading changed its microstructure as electronic exchanges replaced the former business of stock brokers. Thereby, investors gained direct access to equity, instead of access intermediated by stock brokers. This change in market structure has been largely enabled by three factors - namely, the financial-economic environment, regulation and legislation, as well as ICT. Out of these three, our study identifies ICT as the fundamental lever in reducing transaction costs.

This development facilitated trading by investors, who experienced simpler access, cost reductions and increases in trading speed. All previous forms of trading brought about substantial improvements in market performance, thereby attracting larger trading volumes from both institutional and retail investors. Within few years, stock markets significantly increased in size and dominance - the defining theme of financialization.

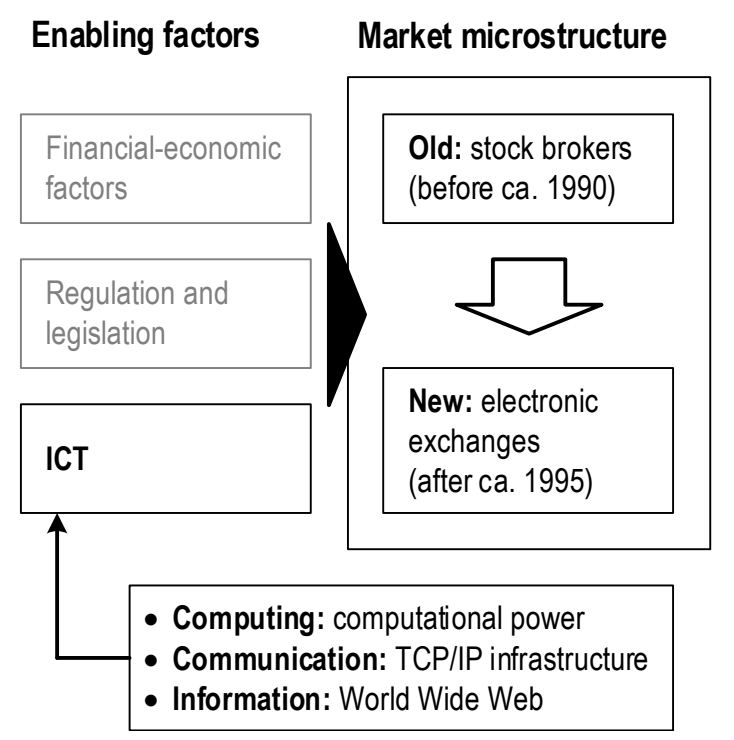

\section{Trading activities}

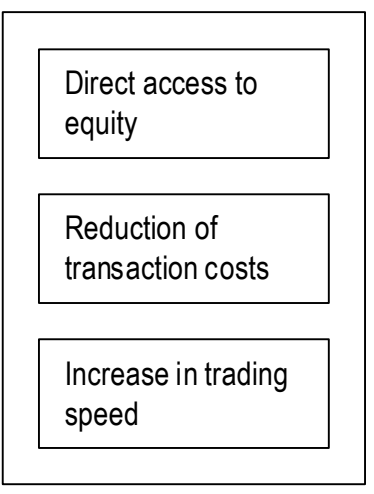

Increase in trading speed

\section{Market performance}

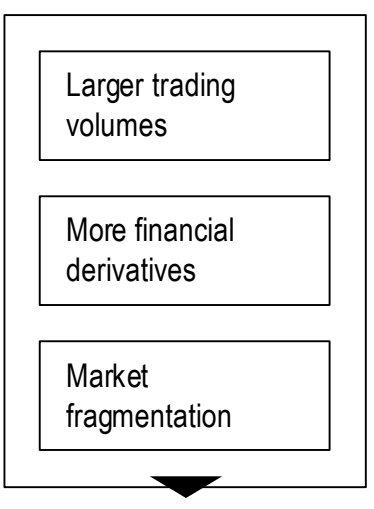

Effect: financialization

Figure 2. Framework highlights information and communications technology (ICT) as the main enabling factor for electronic exchanges. 


\subsection{Market microstructure change from floor to electronic trading of stocks}

For many years, stock market transactions were completed via face-to-face negotiations between buyers and sellers on the physical premises of the stock exchange. This presented considerable market entry barriers for retail investors wishing to participate in direct trading activities.

As a remedy, Black (1971a) suggested the concept of a fully-automated stock exchange by means of ICT, whereby investors could interact with one another with almost no human intervention. He noted that "a stock exchange can be embodied in a network of computers, and the costs of trading can be sharply reduced, without introducing any additional instability in stock prices" (Black, 1971b, p. 87). Such electronic orders were later rendered technically possible. For instance, the New York Stock Exchange (NYSE) introduced a designated order turnaround system in the late 1980s, which routed electronically submitted orders directly to the trading floor, instead of through a broker. However, human traders still had discretion over the order in which to execute trades (Huang and Stoll, 1996). It took the NYSE a number of additional years to develop the automatization of its trading system. Similarly, the Nasdaq stock market adopted ICT in order to progress towards an automated trading system (Berkeley, 1997). Accordingly, the Nasdaq “owes its very existence to information and communications technology” (Stoll, 2006).

With the increasingly widespread acceptance of ICT, the monopoly enjoyed by the "traditional" exchanges around the globe has been replaced by a system in which each exchange competes with another for liquidity and order volume. To this end, existing exchanges have been forced to develop new business models in the interest of better trade execution.

With the growing prevalence of electronic stock trading, possible entry barriers for stock traders were lowered. The earlier system of floor trading only granted intermediated access to equity, while ICT eventually helped retail investors invest in equity directly. We detail the consequences of this market structure change for traders in the following sections.

\subsection{Enablers of electronic stock trading}

Our framework identifies three factors that potentially enable electronic stock trading, which we thoroughly discuss in the following sections. In brief, ICT represents the main driver of 
electronic stock trading. Literature commonly mentions two other possible enablers - namely, financial-economic factors, as well as regulation and legislation.

\subsubsection{Financial-economic factors}

This group subsumes enablers that stem from the macroeconomic environment or the financial industry itself. In particular, it embraces the creation of new financial products, which is referred to as financial innovation. Financial innovation has frequently been a key driver in fundamental shifts of financial market structure (Merton, 1995; Tufano, 2003), as discussed in the following.

On the one hand, financial innovation designs new financial products that allow investors to invest in asset classes that were previously restricted to dedicated players. For instance, the invention of financial future contracts made commodities investable without the need to maintain storage facilities.

On the other hand, financial innovation can also reduce transaction costs - for instance, through the creation of exchange traded funds (ETF). ETF make it possible to invest in an entire index of stocks at considerably lower costs and thus broaden the number of retail investors participating in financial markets (Lechman and Marszk, 2015). Accordingly, this instrument has gained significant traction over the past years. For instance, the S\&P SPDR, the first ETF in the U.S., now manages over USD 86 billion in assets, with a turnover of 250 million shares on an average day. Lastly, the potential downsides of financial innovation should not be left unnoted.

In the past years, high-frequency trading (Chordia et al., 2013; Seddon and Currie, 2016) has further reduced transaction costs, since liquidity is now not only provided by specialists or market makers. The collapse of bid-ask spreads is seen as a direct consequence of this development (Hendershott et al., 2011).

\subsubsection{Regulation and legislation}

Financial regulation is critical in shaping a favorable environment for investments, since governments can impose direct levy or taxes and thereby significantly increase the costs of investing (as showcased by the recent example of the European financial transaction tax). Furthermore, 
regulators can also trigger indirect transaction costs by setting minimum capital rules or collateral requirements.

Regulators and legislators also have the power to restrict investments into specific assets. For example, the U.S. only allows accredited investors to invest in venture capital funds, according to Rule 501 of Regulation D. Similarly, governments can facilitate the inflow of foreign capital, by granting foreign investors access to local markets.

Beyond setting the boundaries for investments, regulators are critical in shaping market microstructure through regulation. In this context, stock exchanges have been forced to develop new business models in the interest of efficiency and fairness. This development was driven by a number of specific proposals, e.g. Regulation ATS enforces the collection of order records and transparency reporting, similar to the requirements of MiFID II in the European Union. Furthermore, until 2000, Rule 390 required NYSE traders to receive prior permission before trading.

Regulation and legislation are often regarded as an enabler for financialization (LagoardeSegot, 2016). Undoubtedly, deregulation has contributed to the growth of electronic stock trading (Stockhammer, 2010). For instance, the growth of high-frequency trading is due the regulatory environment, including the Regulation National Market System (Reg NMS), which is intended to promote efficient price formation in exchanges. While regulation and legislation have increased trading volumes and made latency reductions from ICT apparent, there is no apparent shift in international regulation that by itself seems a likely explanation for the rise of electronic trading alone.

\subsubsection{Information and communications technology as the key enabler}

Several advancements in ICT were necessary in order for ICT to enable direct access to equity. We group the underlying drivers of change into the areas of computing, communications and information as follows:

- Computing (computational power). Until the 1980s, computing resources had been too limited to handle multiple trades simultaneously. However, substantial enlargements 
in computational power at the end of the 1980 s rendered it possible to process large volumes of trade data or execute orders in real time. Research had already concluded by 1989 that "there is no question that the faster rate of completion of deals provided by computers speeded events by a factor of ten" (Holloway, 1989, p. 106). Likewise, Nasdaq established a new trading facility in 1996 that allowed for the processing of two billion shares per day - an amount that had been previously unheard of (Berkeley, 1997). Nowadays, computational capabilities can scale almost indefinitely.

- Communication (TCP/IP infrastructure). Probably the most crucial ICT advancement that led to the emergence of electronic trading platforms was the increasing ubiquity of remote connectivity. During the 1990s, the Internet grew beyond its primary, researchoriented roots to embrace both a broader user base and soaring commercial activity. As a result, vendors started to incorporate TCP/IP technology into their products in the early 1980s (Campbell-Kelly and Garcia-Swartz, 2013). As such, the availability of broad connectivity motivated firms to commercialize their products via the Internet (Huang et al., 2003). The Internet later started to find its way into private households, as well (Campbell-Kelly and Garcia-Swartz, 2013), thereby allowing individuals to submit trades from home.

- Information (World Wide Web). The growth of the World Wide Web triggered a radical change in the dissemination and availability of information. Suddenly, detailed, companyrelated information was at the finger tips of investors whenever they desired access. Examples of such information include press announcements, corporate reports and regulatory filings such as those required by the U. S. Securities and Exchange Commission (SEC). In addition, the Internet allows retail investors to compare quotes from different markets in real time. This ultimately results into a drastic reduction of search costs (Bakos, 1997).

We hence conclude that innovations in ICT represent the core enabling factor for the electronicification of stock trading. 


\subsection{Electronification of stock trading facilitated trading activities}

The above advancements in ICT resulted into three core improvements for trading - namely, direct access to equity, reduction of (explicit) transaction costs and increases in trading speed (Allen and Santomero, 2001; Parker and Weber, 2014). These three items greatly facilitated the trading activities of investors and the growing prevalence of electronic stock exchanges, as will be shown below.

Direct access allowed investors, for the first time, not to rely on established brokers. Instead, market participants were able to initiate orders directly through online channels. As such, electronic trading systems based on electronic communications networks removed geographical constraints and enabled continuous, multiparty interactions in the exchange markets (Bank for International Settlements, 2001). Soon after the introduction of electronic exchanges, their trading volumes exceeded those from brokers (Jain, 2005).

Electronic exchanges have significantly lowered explicit transactions costs (fees, commissions and spreads) in comparison to stock brokers. For instance, average round-trip commissions per trading volume declined from $1.17 \%$ in 1980 to $0.21 \%$ in 2001 (Stoll, 2006). Hence, researchers argue that "perhaps the clearest contribution of technology to market development is the reduction in trading costs" (D'Avolio et al., 2001). In fact, transaction costs represent a crucial driver of costs, since they can easily become economically significant (Keim and Madhavan, 1997). Accordingly, research has addressed this challenge by proposing different pricing models for securities trading (e.g. Clemons and Weber, 1997).

Direct access allowed for faster trading speed and, consequently, triggered the rise of highfrequency trading. It now allows investors to complete thousands of trades within fractions of a second (Chordia et al., 2013; Seddon and Currie, 2016).

In addition, the above changes implicitly lowered existing market entry barriers. Originally, access to market liquidity occurred through the on-site network of brokers or institutional overthe-counter trades - both of which entailed high set-up and maintenance costs. In contrast, electronic stock trading harnesses economies of scale and thus benefits from a reduction in fixed costs and costs for manually processing each transaction (Bakos, 1991). In the past, brokers also 
had privileged access to information, in particular to real time prices; however, this circumstance was also diminished by electronic trading (Bakos, 1997).

\subsection{Improvements in market performance}

The above market determinants have resulted in further improvements in market performance. First of all, we observe larger trading volumes for both retail and institutional investors (D'Avolio et al., 2001; Weber, 2006). For instance, trading volumes of corporate equities have more than tripled in a 10-year period in the U.S. and, similarly, annual stock market turnover rose from $33 \%$ of the U.S. GDP in 1988 to $383 \%$ in 2008 (Stockhammer, 2010). Furthermore, fewer than 200,000 trades were placed via the Internet on an average day in the beginning, while this number exceeded 1.3 million by early 2000 (D’Avolio et al., 2001). Out of these trades, around $48 \%$ stemmed from retail investors (D'Avolio et al., 2001). Hence, we observe an "explosion of online trading by 'self-directed investors'” (Bakos et al., 2005, p. 354), as a large share of trades originates from retail investors.

Furthermore, we see a strong indication that market liquidity - and thereby its efficiency has improved as a result (Bakos et al., 2005; Dewan and Mendelson, 2001; Reck, 1998). For instance, bid-ask spreads have decreased from $0.21 \%$ in 1980 to $0.07 \%$ in 2001 (Stoll, 2006).

The growth in financial derivatives serves as a prominent indicator of financialization and was a central element in the 2007/08 financial crisis. However, the rapid increase in the use of financial derivatives appears not to be a direct consequence, although it would not have been possible without the electronification of trading.

Furthermore, market fragmentation has also been subject to change, but not necessarily as expected. The reduction of market entry barriers encouraged new service providers to offer electronic trading platforms that directly challenged the main incumbents, such as Nasdaq and NYSE. As a result, the earlier expectation of an inevitable consolidation of exchanges did not hold true, as smaller exchanges were able to carve out their own customer bases (Madhavan, 1995; Stoll, 2006). On the contrary, ICT fostered an "explosion of alternate trading venues" such as electronic communications networks to match buyers and sellers (Bakos et al., 2005, 
p. 354).

ICT advancements in data transmission speed also enabled a entirely new dimension of trading, i. e. high frequency trading, also referred to as low latency trading (Hendershott et al., 2011; Seddon and Currie, 2016). It is estimated that, in 2015, about two-thirds of all trades in the U.S. equities market fell into this category (Gomber and Haferkorn, 2013).

\subsection{Financialization of stock trading as the outcome}

All of the above factors acted as critical accelerators of financialization and thus increased the dominance of financial markets and their actors. As mentioned in our introduction (see item c), we follow the notion by which financialization is measured by looking at the trading volumes on an asset level. Over the years, trading volumes of electronic exchanges have grown enormously (Lucas et al., 2009; Weber, 2006). As a result, the time span from 1990 to the mid 2000s saw a consistent and sharp increase in financialization in the equities market (Epstein, 2005; Krippner, 2005; Palley, 2013).

\section{ICT and the financialization of credit: The case of marketplace lending}

We now utilize the above framework to better understand the financialization of credit and its extraordinary similarity to the emergence of electronic trading. We therefore adapt the earlier framework on ICT and the financialization of stock trading for marketplace lending; see Figure 3.

Accordingly, advancements in ICT also lowered market entry barriers by allowing direct investments into credit liabilities. This section thus identifies ICT the key driver for this change in the market microstructure. As a result, marketplace lending is currently disrupting the market of consumer credit. According to interviewee 34, "so far, banks have always maintained a quasi-monopoly of issuing credit. This may be about to change now."

The new market microstructure provides benefits for investors, as direct access is now possible, costs have decreased and loans are processed more quickly. Consequently, we observe enhancements in market performance, as reflected by growing trading volumes. Altogether, this 
is causing a further process of financialization, but this time of credit. We detail each of the above components of the framework in the subsequent sections.

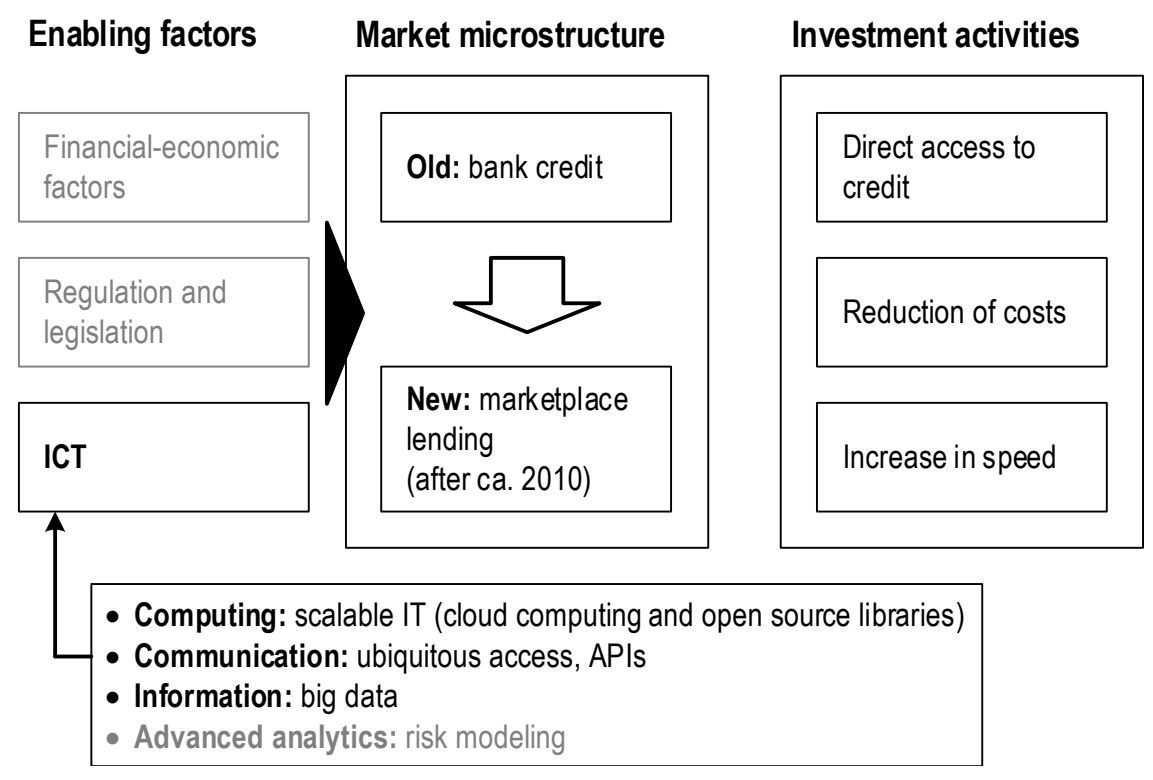

Market performance

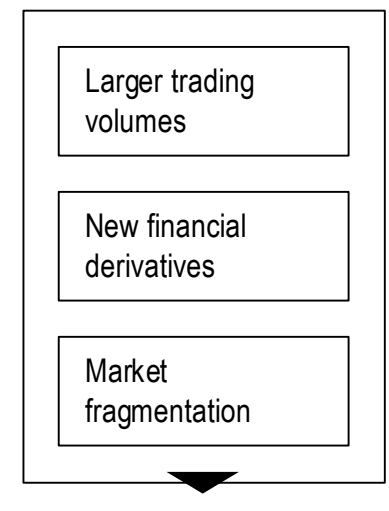

Effect: financialization

Figure 3. Our framework applied to marketplace lending highlights ICT as the main enabling factor, eventually driving a new wave of financialization.

\subsection{Market microstructure change from the traditional banking model to mar- ketplace lending}

\subsubsection{Banks as the traditional provider of credit and barriers to entry}

According to traditional economic theory, banks fulfill an elementary role within the economy. Table 4 details their functions. First, banks provide brokerage by connecting borrowers and depositors who would otherwise not know of each other. In addition, banks contribute transformation services as they change the underlying economics of loans to make them suitable for retail exposure. In particular, banks provide short-term liquidity while lending long term. They also accept small deposit volumes and mitigate risk by distributing individual credit risk over the entire portfolio. 


\begin{tabular}{|c|c|c|c|}
\hline Functions & Traditional banking & Securitization model & New marketplace paradigm \\
\hline \multicolumn{4}{|l|}{ Brokerage } \\
\hline Access & $\begin{array}{l}\text { Access to consumer credit only } \\
\text { for banks }\end{array}$ & $\begin{array}{l}\text { Access only through banks and } \\
\text { SPV vehicles }\end{array}$ & Direct access to individual loans \\
\hline Economies of scale & $\begin{array}{l}\text { Large scale necessary due to } \\
\text { high fixed costs }\end{array}$ & $\begin{array}{l}\text { Large scale important given addi- } \\
\text { tional SPV structuring costs }\end{array}$ & $\begin{array}{l}\text { Efficient at low scale because of } \\
\text { ICT }\end{array}$ \\
\hline Privileged information & $\begin{array}{l}\text { No public information about } \\
\text { borrowers available }\end{array}$ & $\begin{array}{l}\text { Aggregated information for in- } \\
\text { vestors (portfolio rating) }\end{array}$ & $\begin{array}{l}\text { Detailed information about individ- } \\
\text { ual loans for investors; credit scor- } \\
\text { ing by platforms }\end{array}$ \\
\hline \multicolumn{4}{|l|}{ Transformation } \\
\hline $\begin{array}{l}\text { Transformation of loan } \\
\text { maturity }\end{array}$ & $\begin{array}{l}\text { Short-term deposits but long- } \\
\text { term credit, over-leverage and } \\
\text { thus risk of bank runs }\end{array}$ & $\begin{array}{l}\text { Limited, but secondary market liq- } \\
\text { uidity }\end{array}$ & $\begin{array}{l}\text { Limited maturity transformation } \\
\text { and limited liquidity, no risk of } \\
\text { bank runs }\end{array}$ \\
\hline $\begin{array}{l}\text { Transformation of unit } \\
\text { size }\end{array}$ & $\begin{array}{l}\text { Continuous depositing into ac- } \\
\text { counts possible }\end{array}$ & $\begin{array}{l}\text { High minimum investment require- } \\
\text { ments }\end{array}$ & $\begin{array}{l}\text { Fractional investment into loans in } \\
\text { small lots possible }\end{array}$ \\
\hline Risk transformation & $\begin{array}{l}\text { Banks distribute individual } \\
\text { credit risk }\end{array}$ & $\begin{array}{l}\text { Portfolio effect; additional third- } \\
\text { party insurance and credit enhance- } \\
\text { ments }\end{array}$ & Risk to be managed by investor \\
\hline
\end{tabular}

SPV: special purpose vehicle (i.e. a legal entity created to isolate risk in equity)

\section{Table 4. Comparison of the traditional banking model, securitization and the new marketplace paradigm.}

The function of brokerage presented a significant market entry barrier for potential competitors in the past. As a result, banks benefited from several circumstances (see Table 4): first of all, access to customers traditionally occurred through physical branches, which were costly to build and maintain, as well as requiring a large sales force. Second, the setup of banking systems used to demand expensive and time-consuming investments into enterprise solutions and information technology (IT) infrastructures. Hence, large numbers of loans are necessary for economics of scale. Third, lending requires accurate predictions of default, as well as suitable pricing. Here, banks were to harness their privileged access to historic information, which helped them reduce information asymmetries.

\subsubsection{The new business model of marketplace lending}

Finally, the arrival of marketplace lending fundamentally changed the rules of the game. Examples comprise companies such as Prosper and Lending Club, founded in 2005 and 2006, respectively, as first of their kind in the U.S.. Marketplace lenders allow prospective borrowers to publish loan requests on their online platform. Other individuals or institutions can then decide to lend money to those borrowers directly, based on the published loan characteristics. The 
entire process is completed online, without any physical bank branch visit or personal human interaction. As a result, marketplace lenders facilitate a direct connection between lenders and borrowers without going through a traditional financial intermediary, such as a bank (cf. Figure 5), and have thus replaced banks in their brokerage function.

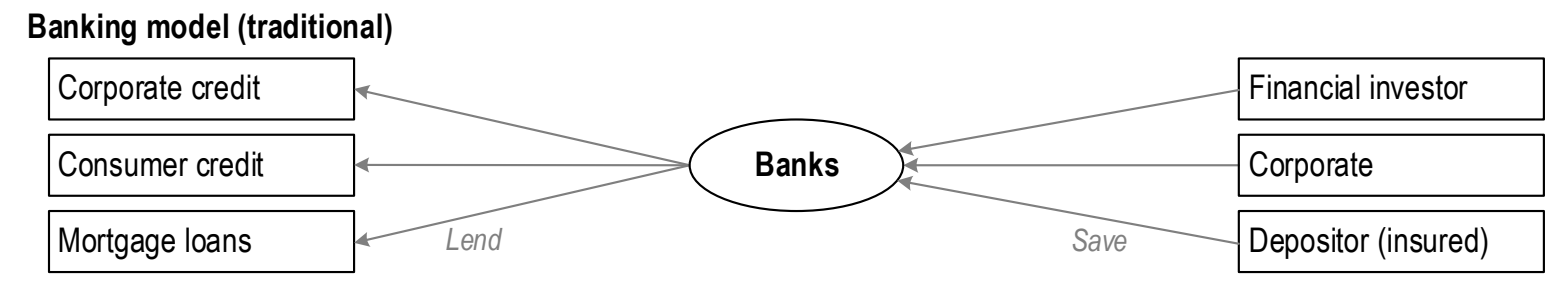

Securitization model (since 1960s)

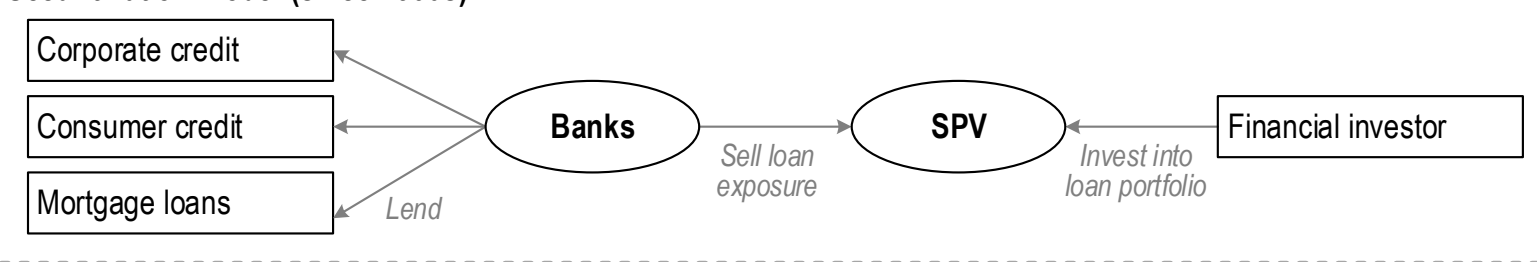

Marketplace lending model (since 2005)

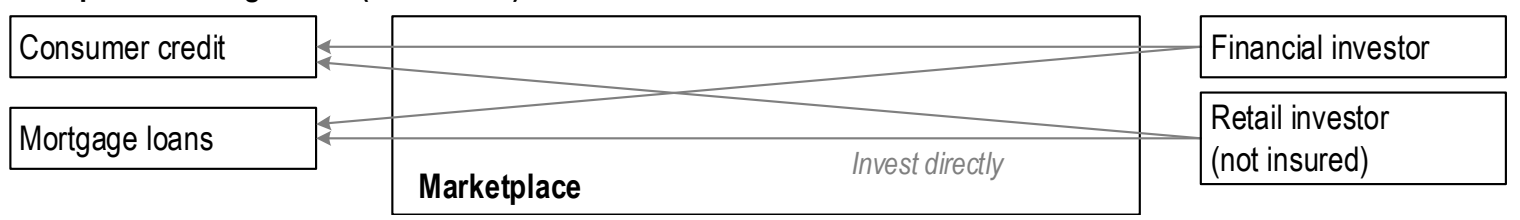

Figure 5. Schematic comparison of traditional banking model, securitization and marketplace lending. Here, SPV stands for special purpose vehicle.

Nowadays, a large number of marketplace lenders competes for market shares in numerous loan segments across the world. Examples include OnDeck (specializing in small business loans), SoFi (student loans) and LendInvest (mortgage loans).

\subsection{Enablers of marketplace lending}

In order to identify relevant enablers, we predominantly rely on interviews, as perceived outcomes are largely qualitative by nature. For this purpose, we have interviewed relevant experts from the financial industry, the financial technology (FinTech) sector and the field of marketplace lending, mostly at a C-suite level (see the appendix for a full list of interview partners). We provide selected quotes to underpin our findings. Similar to the introduction of stock trading, we 
can attribute only a minor role to financial-economic factors, regulation and legislation. Rather, we identify ICT as the main enabler.

\subsubsection{Financial-economic factors}

Several financial-economic factors triggered the desire of investors for non-intermediated access to loans. First of all, the financial crisis 2007/08 led investors to question the quality of securitized loans provided by banks. In fact, the securitization model was intended to promote risk management by structuring entire portfolios. However, as the financial crisis revealed, the default risks within many structured portfolios tended to be heavily correlated and the desired risk diversification, therefore, did not take place (Stein, 2010). As a consequence, the market dried up considerably and the resulting availability of credit primarily triggered the financial crash.

In addition, purely financial motives increasingly started to take hold within banks. In keeping with the concept of originate-to-distribute, banks would issue loans only with the clear intention of selling them at a profit to financial investors soon after. Based on a study by the Federal Reserve Bank of New York, U.S. banks sold 56.3\% of all term loans originating in 2007 to non-bank investors, a 327 percentage point increase from fifteen years earlier (Bord and Santos, 2012). This practice seems to have unambiguously fostered moral hazard. Accordingly, studies have shown that banks were originating "excessively poor-quality" loans when those loans were to be sold later (Purnanandam, 2011).

Back then, banks also paid ratings agencies for the credit rating of their products. As a result, the signaling quality of credit ratings diminished and investors requested the opportunity to assess credit default, not of securitized portfolios, but of individual loans.

\subsubsection{Regulation and legislation}

When the first marketplace lenders emerged in the U.S. in 2006, the applicable regulatory framework was originally left unclear, since no tailored legislation or specific regulation to govern marketplace lending was yet in place. Accordingly, "regulation did neither stop us nor materially help us. We had to [... ] find our own way forward" (interviewee 9). 
However, given the growing importance of such lenders and the undeniable similarities of the business model to that of a bank, marketplace lenders soon attracted the attention of the regulatory body in the U.S., the SEC. As one observer remembers, "they looked at those companies and said - if it quacks like a duck and walks like a duck, shouldn't we regulate it as a duck?" (interviewee 9). To set a precedent, the company Prosper was banned from issuing loans in 2007, after the SEC decided to apply securities law and financial markets regulation to marketplace lending. Subsequently, the company shut down for 13 months in order to reshape its business model. Henceforth, Prosper was required to file each loan as financial security, but was allowed to recommence operations. As a fundamental difference to traditional banks, marketplace lenders are not required to hold regulatory capital in the U.S.

Over the years, the regulatory framework evolved to cater to the specific requirements of marketplace lending. To date, different countries have created highly diverse regulatory frameworks, ranging from a separate license for marketplace lenders to the application of full banking law (cf. the cross-country comparison later). Despite the differences, marketplace lending is growing rapidly in all countries, indicating that the common enabling factor has to be found outside of regulatory issues. It is thus legitimate to conclude that regulation neither prevented nor acted as key enabling factor in the initial growth of marketplace lending.

\subsubsection{Information and communications technology as the key enabler}

Starting in the mid 2000s, progress in ICT dramatically lowered market entry barriers, that had originally prohibited competitors from challenging the established banks (cf. e. g. Kaniadakis and Constantinides, 2014, for securitization). As one CEO points out, "it took Wells Fargo 150 years to get where they are today. Now, with some [investment] money, we are able to set up a vital banking business in three months with only 80 people - as long as half of them are [IT] engineers and UX designers" (interviewee 6).

Based on our interviews, we have identified a subset of ICT innovations that were key for the introduction of marketplace lending, as well as its rapid growth. Parallel to electronic trading, we find salient themes in the areas of computing, communication and information: 
- Computing (scalable IT via cloud computing and open source libraries). On the hardware side, marketplace lenders have neither the resources nor the budget to construct massive server installations or complex software infrastructure from scratch. Hence, the advent of cloud computing suddenly allowed marketplace lenders access to practically infinite computing power, since cloud computing scales with demand and has a short-term availability once needed (Armbrust et al., 2010; Venters and Whitley, 2012). Consequently, it eliminated almost completely the upfront investments in computing power, which had hitherto served as a massive barrier to market entry.

On the software side, modular software components eased the development of entire IT systems for banking (Haas et al., 2015). For instance, programming languages such as Python ship a vast range of open source libraries, pre-assembled packages, or even web frameworks (e.g. Django). Therefore, available frameworks have accelerated the process for building new software. "Maybe the biggest difference-maker is that those massive lines of codes and pre-built items are available online at literally no costs. It allows us to replicate processes and operations of larger scale that would have required us [...] probably a [EUR] 100 million investment” (interviewee 15).

- Communication (ubiquitous access and API infrastructure). Even as recently as ten years ago, a physical bank branch was the only place to file loan applications. However, ubiquitous access nowadays allows virtually every citizen to access banking services around the clock via online and mobile connectivity. "Now, someone can apply for a loan from their mobile from anywhere on the planet, 24/7" (interviewee 7).

Until recently, identity verification acted as one of the last obstacles to the widespread adoption of online services, as legal requirements forces individuals to verify their identity in a physical branch. Recent advancements in biometric verification and image recognition technology now allows lenders to automatically verify identities of individuals remotely. For instance, our industry experts name a range of biometric systems that are in use today, including fingerprint readers and voice recognition, while face recognition and behavioral pattern identification are still in the pilot stage. 
In addition, the availability of a comprehensive application program interface (API) infrastructure constitutes another crucial enabler. As an example of its relevance, a large service providers revealed us that they are currently handling more than 50 billion API calls per month (interviewee 24). Even though the concept of an API has been key to software development for many years, only the arrival of the Internet and high-speed data connections have established fully-distributed systems across companies. Accordingly, APIs especially support both (a) outsourcing of activities and (b) gathering of data. With the help of outsourcing, marketplace lenders can operate as an agile start-up and concentrate on their core business. The latter allows companies to outsource tasks to third-party service providers which bear the responsibility for back office duties, as in traditional banks. In practice, both approaches function through fully-automated API landscapes in almost real time.

APIs have also become essential in sourcing financial data, while ensuring a fast transaction speed. For instance, credit bureaus grant access to their data through APIs. Similarly, major providers of accounting software for small businesses, such as Xero or Intuit, provide an open interface for accounting data. Hence, marketplace lenders can easily access the entire cash flow history of a small business borrower, which is a much richer source of information than most banks would traditionally incorporate into their risk models. As another example, the company Yodlee sells an API through which marketplace lenders can download the entire transaction history from a prospective borrower's bank account. This is possible only with agreement from the owner of the bank account, but without consent of the corresponding bank.

In addition, APIs can also be used to source external data, since many services and social media platforms released corresponding APIs for fully-automated and real time access to their data in the late 2000s. For instance, prevalent platforms, such as Ebay, Facebook or Twitter, have all opened up access to their APIs. This provides a rich source of unstructured or "big data" that is increasingly used to assess creditworthiness (as outlined below).

- Information (big data). The recent rise of big data has found its way in various industries 
(Bhimani, 2015; Woerner and Wixom, 2015) and the availability of big data also fulfills a critical prerequisite for predictive tasks in the lending business. In contrast to banks, marketplace lenders have no transaction history with the prospective borrower. Instead, they can rely on today's availability of big data in order to collect a basis of information sufficient for accurate assessments of credit risk.

The underlying sources of big data encompass a wide range of origins. Hence, the data is highly heterogeneous and often appears in unstructured formats. Examples include social media profiles, calendar data, browsing history, mobile phone connection data, satellite images and even behavioral profiles. Analyzing these data sparks insights into the habits and reliability of borrowers, far beyond their formal credit score. Already, specialized FinTech companies, such as KreditKarma and Lenddo, have built their core business around the analysis of big data in order to sell aggregated credit scores to marketplace lenders. However, we note that the availability of information is always subject to the constraints of data regulation in the corresponding country.

We initially expected that most marketplaces would leverage big data with the help of advanced analytics and would employ highly sophisticated risk models. However, contrary to our initial assumption, our expert panel did not perceive advanced analytics as one of the main enablers. According to them, most of the current methodologies for risk assessment have been known for years. Examples of rather advanced methods in use include multivariate adaptive regression splines, recursive neural networks, time series analysis and random forests (we omit frequencies here to conceal the trade secrets of our interview partners). Many recent platforms seem to start with rather standard analytical approaches, such as a linear regression. As one observer commented, "the smaller marketplaces employ about 50 people all-in when they launch operations. Resources to develop 'fancy' analytics tools are, frankly, rather limited. [...] They have to start basic" (interviewee 15).

In the context of advanced analytics, many interview partners anticipate significant potential to translate findings from research into better risk models. Artificial intelligence, in particular, is expected to offer considerable improvements in the near future and is thus also projected 
to become a strategic competitive advantage. "We are also monitoring closely what happens in the online community. For instance [...], we regularly screen Kaggle to see if we find any new and exciting [methodology]. We then use it to try and get this extra bit of improvement" (interviewee 9). It is thus no surprise that one notices a clear demand for data scientists across the financial industry.

\subsection{Marketplace lending facilitated investment activities}

Marketplace lending has shaped the business of providing credit in a profound way, yet with noteworthy similarity to the emergence of electronic trading. Foremost, retail investors have been granted, for the first time, the opportunity to directly invest in loans as an asset class of their own (see Table 6). "Marketplace lending now gives John Doe the ability to make money, not from his contractual work, but from trying to assess the credit risk of his fellow citizens", interview partner 4 critically remarks.

\begin{tabular}{lcc}
\hline & $\begin{array}{c}\text { Asset volume } \\
\text { (in USD bn) }\end{array}$ & $\begin{array}{c}\text { Year of first } \\
\text { electronic trading }\end{array}$ \\
\hline $\begin{array}{l}\text { Liquid assets } \\
\text { Corporate equities }\end{array}$ & 12,876 & 1993 \\
Corporate bonds & 4,756 & 1977 \\
\hline Credit liabilities & & \\
Mortgage loans & 459 & 2015 \\
Small business loans & 585 & 2007 \\
Consumer loans & 3,478 & 2006 \\
Trade receivables & 3,440 & 2013 \\
Student loans & 1,200 & 2011 \\
\hline
\end{tabular}

Table 6. Comparison of the first year of electronic trading across different assets. The table also reports their volume in the U.S. in the third quarter of 2015 (source: Federal Reserve Statistical Release, Z.1 Financial Accounts of the Unites States).

Marketplace lending has accelerated the process of granting loans by orders of magnitude in comparison to traditional banking (see Figure 7). For example, the time between a loan application via Lending Club to the time of its distribution to investors is no longer a matter of months, but rather of minutes or even seconds. In contrast, it still takes several weeks until a loan request is approved and fulfilled in the traditional banking world. 


\begin{tabular}{|c|c|c|c|c|}
\hline Process steps & Verification & Data collection & Risk assessment & $\begin{array}{l}\text { Processing \& } \\
\text { administration }\end{array}$ \\
\hline $\begin{array}{r}\text { Traditional } \\
\text { banking } \\
(2000 \mathrm{~s})\end{array}$ & $\begin{array}{l}\text { - Human identity } \\
\text { verification in bank } \\
\text { branch }\end{array}$ & $\begin{array}{l}\text { - Proprietary data } \\
\text { - Physical forms } \\
\text { - Manual checking of } \\
\text { information }\end{array}$ & $\begin{array}{l}\text { weeks } \\
\text { - Manual risk } \\
\text { management } \\
\text { - Models and human } \\
\text { judgement }\end{array}$ & $\begin{array}{l}\text { - In-house processing } \\
\text { (operations, back } \\
\text { office, collections) }\end{array}$ \\
\hline $\begin{array}{r}\text { Marketplace } \\
\text { lending } \\
\text { (as of 2016) }\end{array}$ & $\begin{array}{l}\text { - Online verification } \\
\text { - 3rd party services }\end{array}$ & $\begin{array}{l}\text { - Automated collection } \\
\text { from traditional and } \\
\text { alternative sources }\end{array}$ & $\begin{array}{l}\text { - Mostly automated } \\
\text { risk analysis } \\
\text { - Use of untraditional } \\
\text { variables }\end{array}$ & $\begin{array}{l}\text { - Distributed processing } \\
\text { across 3rd party } \\
\text { services }\end{array}$ \\
\hline ICT enabler & - API infrastructure & $\begin{array}{l}\text { - Big data } \\
\text { - API infrastructure }\end{array}$ & $\begin{array}{l}\text { - Cloud computing } \\
\text { - Advanced analytics }\end{array}$ & - API infrastructure \\
\hline
\end{tabular}

Figure 7. ICT enables a considerably faster processing time of loan applications from marketplace lending in comparison to bank credit.

ICT has granted high-speed access for those looking to invest in loans. Many larger marketplace lenders now offer APIs themselves, thereby increasing the speed with which investors can make investments in loans. The APIs allow investors to instantly receive information about newly available loans. They can then apply their idiosyncratic risk assessment models in real time and make investment decisions based on pre-defined criteria.

Comparable to the practice in high-frequency trading, investors have already started to collocate their servers near the server farm of the marketplace in order to get a time advantage in the area of milliseconds when competing over loans. Some platforms have thus raised concerns that retail investors "are left with the worst [risk-return] profiles of loans after savvy investors had the chance to skim the cream off the top" (interviewee 9). For instance, Lending Club offers such an API and, as a result, automated investments through its API have seen a steep increase, becoming the dominant mode of investment. Accordingly, leading marketplace lenders are investigating the use of speed breaks and certain quota between retail and institutional investors to partially level the playing field again.

To draw a large customer base, marketplaces especially advertise their lower transaction costs in comparison to traditional banks. The inherent characteristics of online marketplaces equip them with the ability to operate at lower costs, as they employ less staff and do not maintain 
physical branches. Therefore, the estimated frictional costs of marketplace lenders in making a loan amount to around 2\%, compared to about 5 to $7 \%$ for a typical bank (Noonan and Arnold, 2015). In addition, marketplace lenders often do not fall under the same regulatory regime and are thus not required to hold regulatory capital against their issued loans. Hence, costs of capital are significantly reduced.

\subsection{Improvements in market performance}

The above characteristics appealed to investors and marketplace lending was thus quickly able to generate great traction. Consequently, its investments have risen exponentially within a matter of years. While marketplace loans were virtually nonexistent in 2010, they exceeded more than USD 30 billion of outstanding volume in the U. S. alone in 2015 (Morgan Stanley, 2015).

In a key difference from the emergence of electronic stock exchanges, marketplace lenders catered particularly to retail investors in the beginning. They built their business foremost around the assumption that institutional investors would not serve as a natural target group for a loan-byloan investment model, since they were already able to invest in (intermediated) securitized loan portfolios. However, institutional investors soon realized the advantages of disintermediation and the financial returns that marketplace lending had to offer. Hence, what started as "peer-to-peer lending" is now dominated by professional investors. For instance, two-thirds of all Lending Club investments come from large institutions, such as hedge funds and asset managers (Lending Club, 2015). Overall, it is estimated that $20 \%$ of the revenues from U.S. marketplace lenders in 2015 originated from retail investors, $50 \%$ from institutional investors and the remaining $30 \%$ from securitizations, which are highlighted below (Jenkins, 2016).

Recent financial innovations have added another layer on top of marketplace lending by developing new financial derivatives. These further exacerbate the role of financial markets with regard to credit. One industry expert comments: "Where investors see money, they will try make money. Why stop here?" (interviewee 27). According to our interviews and recent industry reports, the following financial instruments have already been translated to marketplace lending:

- Investment trusts from marketplace loans. These investment trusts bundle marketplace 
loans and sell shares to institutional or retail investors. Rather than investing in loans directly through online marketplaces, investors now can buy and sell shares from financial vehicles that manage selections of marketplace loans on their behalf. For instance, P2PGI redirects investor money into U. K.-originated marketplace loans with a total asset size amounting to more than GBP 1 billion under management (London Stock Exchange, 2015).

- Securitized marketplace loans. Financial institutions have also started to bundle loans from marketplace lending and sell them as structured securitization portfolios. For example, the first securitized marketplace loan in the U.S. was offered by Eaglewood Capital. In this regard, "what had emerged as innocent peer-to-peer [business] has now become a fierce game of highly professional investors [...], leveraging sophisticated Wall Street instruments" (interviewee 7).

- Credit default swaps for marketplace loans. Securitized marketplace loans have drawn the attention of another financial instrument, the credit default swap (CDS), which allows investors to buy contracts without the underlying asset. In 2015, information emerged that hinted at the introduction of CDS contracts for marketplace loans (Alloway and Scully, 2015). Were this was to transpire, investors would then be able to speculate on the default of loans.

- Short selling of marketplace loans. Short selling presents a tool by which investors can speculate on the decline of particular assets. The availability of the above financial instruments, such as securitized portfolios, has thus rendered it possible to short sell not individuals' marketplace loans but portfolios thereof.

Market fragmentation represents a large difference from the emergence of stock trading, where several electronic exchanges competed for market shares. In the credit market as of 2016, a few national banks dominate the market, while being confronted by two major marketplace lenders - namely, Prosper and Lending Club. In the future, we are likely to observe a further fragmentation of marketplaces, in similarity to stock exchanges. For instance, several dozens of online marketplace lenders have been founded in the U. S. since 2014 according to estimates 
by our interview partners. This expansion is empowered by scalable IT that allows users to put additional companies into operation within months and with limited financial investments. As one bank executive remarks, "I sometimes feel that nowadays anyone can start a credit business, literally in their backyard" (interviewee 5).

\subsection{Financialization of credit as the outcome}

We again assess financialization on an asset level, whereby we examine the trading volumes of the corresponding liability. This approach overlaps with our previous measurement of financialization of stock trading and is consistent with our introduction (cf. item c). Hence, all of the above factors describe evident features of financialization and we thus establish marketplace lending as a driver of further financialization. While the volumes in the U.S. banking market decline, marketplace lending is growing, with a compound annual growth rate of of $46 \%$ (Morgan Stanley, 2015). Furthermore, financial investors have started to build entire ecosystems around this new industry of marketplace lending. This can easily lead to a substantial increase in the size of the financial market, compared to the real economy.

It is hard to overstate the profound impact that marketplace lending has on the structure and functioning of an economy, as well as its contribution to the financialization of credit. It is thus highly likely that this trend of financialization will persist or even accelerates in the future. In a nutshell, "if you want to put it like that, this is a textbook example of financialization [... ]financial markets eventually taking over" (interviewee 30).

\section{Discussion and implications}

\subsection{Implications for borrowers and lenders}

While we have previously discussed the positive implications of marketplace lending, we now address potential downsides. For borrowers, easier access to credit provided by online lenders may support unsustainable consumption levels. For instance, borrowers make less rational choices regarding mortgages or student loans if they know their loans are not held by a bank 
until maturity, but rather held by financial investors (Davis, 2009). This credit access effect can potentially lead to excessive debt and its corresponding downsides.

Retail investors that are becoming direct lenders for the first time may be drawn into a new market where they have little experience. This concern is amplified by the fact that retail investors are increasingly fighting an "unequal battle" (interviewee 13) for the best loan profile against technologically more advantaged professional investors. Similarly, uninformed investors in online trading bear a higher risk (Zhang and Zhang, 2015). Furthermore, individuals typically do not have sufficient financial resources to diversify their portfolio of loans and may instead end up with substantial risk from concentration.

\subsection{Implications for marketplace lenders}

In 2016, marketplace lending can still be considered a nascent trend, as were electronic stock exchanges in 1990. Compared to the overall loan volume of USD 800 billion in revolving unsecured credit, marketplace lending represents a tiny share of slightly more than $1 \%$. However, several sources predict extreme growth rates for marketplace lending in the future. For instance, Morgan Stanley forecasts that consumer loans from marketplaces will reach USD 75 billion, or $8.4 \%$ of total issuance by 2020 (Morgan Stanley, 2015). Hence, marketplace lending is expected to enjoy prosperous times as it lays the groundwork to conquer the colossal credit market.

Nevertheless, it is not unlikely that a certain consolidation will occur over time, as earlier in the case of stock exchanges. For instance, loan applications will decrease in the case of a credit cycle downturn and the industry might thus become a "zombie"(interviewee 11), where marketplaces only manage and wind down existing portfolios. This may "separate the wheat from the chaff" (interviewee 37).

In the face of growing competition, companies face a better chance of survival by having a competitive advantage. A prominent example is that of emplyoing advanced analytics in order to gain more accurate risk assessments. One marketplace lending executive comments: "our current, very complex approach to risk modeling puts us in a disadvantage to those who seek growth for the sake of growth, at least at the moment [...]. In the long run, we trust that our 
strategy is the winning one" (interviewee 9).

Marketplace lenders face lucrative environments in all countries around the globe, even in undeveloped regions. Here, ICT can often reach the population, even in remote areas, through the widespread availability of smartphones. For instance, as of June 2015, Africa had a mobile phone penetration rate of $78 \%$ (Ericsson, 2015). In comparison, this number still amounted to a mere $31 \%$ in the U. S. in 2000 (Bank for International Settlements, 2001). On the back of this trend, numerous financial service providers have emerged in such countries, providing access to finance through simple mobile or web interfaces. For the first time, individuals without previous financial access can suddenly apply for credit. Furthermore, marketplace lenders are even able to estimate creditworthiness in the absence of any credit history by exploiting alternative data sources (e.g. Facebook profiles, satellite images or mobile phone transactions records).

\subsection{Implications for traditional banking}

Similar to incumbent stock exchanges and broker businesses, banks may be challenged in their business model by agile competitors. In contrast to online marketplaces, several banks still maintain core banking systems that were developed in the 1970s, using obsolescent programming languages such as COBOL. This presents a considerable obstacle for banks moving forward. For instance, only a few very specialized employees are able to operate these systems. Hence, banks will face a rising urgency to initiate comprehensive transformation programs.

Banks are, however, not expected to vanish any time soon, similar to the fact that most stock exchanges also continue to persist. It is rather likely that banks will implement improvements to their internal ICT systems and thus improve the efficiency of their processes. Moreover, industry experts also predict an increasing number of partnerships between banks and marketplace lenders. Banks can benefit from the technological capabilities of newcomers, while the online platforms gain access to the large customer base of banks. Only recently have the first such partnerships been announced: e.g. Citibank is partnering with Lending Club and J. P. Morgan Chase with the small business lender OnDeck. 


\subsection{Implications for financialization}

With further financialization, co-movements between different asset classes are likely to increase. For instance, commodity prices had little co-movements with stock prices and with each other, until financialization took hold of this asset class (Adams and Glück, 2015; Erb and Harvey, 2006; Tang and Xiong, 2010). This, in turn, could mean that movements on stock markets will now also affect consumer credit viability and the value of consumer loans traded in secondary markets.

Furthermore, it is arguably more difficult to predict systemic risk when prices become more connected across different asset classes. The massive use of financial derivatives, especially, creates systemic interdependencies that are almost impossible to distill. Hence, the result might also be an increasing instability of financial markets. Likewise, securitized marketplace loans amplify the complexity of products and their interconnectedness with the overall financial market, as the International Organization of Securities Commissions (IOSCO) warned in a 2014 report. In addition, these securitized loans also expose the industry to even greater interest rate risk.

\subsection{Implications for regulation and legislation}

Marketplace loans in the U.S. are now a legitimate, regulated asset class, comparable in nature to unsecured loans from banks. In the case of, for example, Prosper, every single loan is issued as a security regulated by the SEC. However, we expect regulators to exercise further tightening and stricter enforcement of rules for marketplace lenders in the future. "The regulators were taken by surprise by the emergence of marketplace lending. But they are catching up" (interviewee 15). As a prominent example, the court case of Madden v. Midland in August 2015 already points towards tighter regulation in the U.S., where Lending Club was forced to adhere more strictly to banking regulations.

The reasons for this development are various in nature. Foremost, marketplace lenders take over the role of banks as the providers of credit and are thus subject to the corresponding systemic interdependencies. Furthermore, regulation is supposed to protect investors, especially as we notice the increasing participation of private investors in financial markets and their exposure to 
un-intermediated risk once they become lenders in online marketplaces.

Most likely, regulatory bodies will not only enforce stricter rules but also develop dedicated standards to govern marketplace lending platforms. In this respect, various measures appear viable, among them minimum capital requirements, obligatory transparency of loan data and compulsory stress tests. In addition, stricter security standards are also expected to follow, since a purely online environment runs a significantly higher risk of potential attacks and fraud. Cybersecurity will be of increasing focus, given recent attacks on prominent financial institutions (e. g. Morgan Stanley among others). As a case in point, the European Union has just passed its directive on security of network and information systems (NIS Directive) in July 2016, aiming to enforce stricter standards for network security. Regulators might also augment the requirements for online verification methods, asserting stricter rules on alternative verification methods, such as video identity recognition. Finally, with increasing customer sensitivity to privacy, legislation may set stricter limits to the collection, storage and use of personal data. The above initiatives might even become multinational standards, as e. g. the SEC sees disadvantages in a fragmented regulatory architecture (Tett, 2015).

\subsection{Cross-country comparison of marketplace lending}

The previous sections predominantly address the U.S. credit market and we thus present a cross-country comparison of different regulatory approaches and banking systems in Table 8 . Marketplace lending might achieve a high rate of utilization in countries with less regulation and rapid financial growth. In this regard, banks have traditionally played only a minor role in countries such as India or many African states, where the majority of the population has long been excluded from the formal banking system.

In an international comparison, China currently represents the largest market for marketplace lending, with loan volumes totaling more than USD 50 billion on the one hand, and more than 2,000 marketplace lenders competing over customers on the other (Morgan Stanley, 2015). Chinese regulators have become increasingly restrictive towards marketplace lenders after several prominent failures with billions of RMB lost. It is generally anticipated that marketplace 
lenders will soon have to fulfill much stricter regulatory requirements consisting of, for example, maximum leverage ratios, minimum capital requirements and tighter oversight.

While China stands among the pioneers in implementing stricter governance regimes, the regulatory approach to marketplace lending varies significantly across jurisdictions. As Table 8 shows, regulations stretch from a dedicated, sometimes "light-touch" platform status to exercising full banking regulation.

For instance, in Europe, regulation of the marketplace lending industry is still under national authority and, therefore, very different rules apply. However, the European Commission is currently in the process of implementing its far-reaching General Data Protection Regulation, which would have significant ramifications on the business model of marketplace lending in all European countries (see European Union, Directive 2016/679). This regulation directive proposes the principle of privacy "by design and by default" (Article 25). As a result, marketplace lenders could be severely inhibited in their use of big data pertaining to individuals.

Regardless of the vast differences in the local environment and respective market idiosyncrasies, marketplace lending seems to be growing inexorably across countries and continents. In spring 2016, the number of nations with at least one marketplace lender operating has surpassed the mark of 80 . Hence, marketplace lending has become a truly global phenomenon.

\begin{tabular}{|c|c|c|}
\hline Regulatory approach & Description & $\begin{array}{l}\text { Selected countries } \\
\text { (where applicable) }\end{array}$ \\
\hline Dedicated platform status & $\begin{array}{l}\text { Platform needs approval from } \\
\text { regulator, based on dedicated } \\
\text { legal status }\end{array}$ & $\begin{array}{l}\text { U. K., U.S., China (up- } \\
\text { coming) }\end{array}$ \\
\hline Banking regulation & $\begin{array}{l}\text { Platforms mainly regulated as } \\
\text { banks }\end{array}$ & France, Germany, Italy \\
\hline Intermediary status & $\begin{array}{l}\text { Marketplaces are regulated } \\
\text { as financial intermediaries or } \\
\text { payment providers }\end{array}$ & $\begin{array}{l}\text { Australia, Argentina, } \\
\text { Canada, New Zealand }\end{array}$ \\
\hline Unregulated or exempted & $\begin{array}{l}\text { Marketplace lending is either } \\
\text { exempted from regulation or } \\
\text { the status remains undefined }\end{array}$ & $\begin{array}{l}\text { Brazil, Ecuador, Egypt, } \\
\text { South Korea, Tunisia }\end{array}$ \\
\hline
\end{tabular}

Table 8. Comparison of regulatory approaches to marketplace lending across selected countries. 


\section{Conclusion}

The emergence of financialization has fundamentally changed the mechanisms of the world economy - in the past, in the present and most likely in the future. This development is prominently seen in financial markets, which have become more fragmented, complex and globally interconnected. Yet the consequences affect not only markets and their stakeholders, but also society as a whole. It is thus not surprising that financialization is receiving considerable attention from researchers in finance, economics, sociology and politics.

In contrast, information systems as a discipline has only recently started to address the relationship between financialization and ICT. Yet both are deeply connected, as revealed by the flash crash of 2010 among others. Relentless advancements in ICT first disrupted the floor-based trading, facilitating its displacement by its electronic counterpart, while the credit business is currently undergoing a substantial shift - away from banks as intermediaries and towards online marketplace lending. This enables direct access to consumer credit for investors as an asset class of its own.

The recent rise of online marketplaces is largely traceable to innovations in ICT. Similar to the electronification of stock trading in the 1990s, progress in computing, communication and information technology has allowed marketplace lenders to prosper across the world. This paper has identified the following elements in particular, which have lowered market entry barriers and have thus enabled the recent growth of marketplace lending: scalable IT infrastructures, ubiquitous access, widespread and extensive APIs, as well as the availability of big data. These ICT enablers were identified based on interviews with almost 40 industry experts and they collectively facilitate new firms entering the market, which operate efficiently on both a small and large scale. According to our interviews, advanced analytics plays only a minor role in the status quo; however, our interview partners expect advanced analytics to yield a competitive advantage in the future.

Online marketplace lending poses a stiff challenge the current banking industry, since these marketplaces are able to disintermediate traditional financial institutions. Simultaneously, they offer highly customer-oriented services and rapid transaction execution at significantly lower 
costs. Already, this trend has become too large to ignore. If the current rate of growth continues, consumer loans that originate from online marketplaces may constitute more than $10 \%$ of total loan issuance by 2020. From being a small niche only few years ago, this phenomenon has the potential to fundamentally change the very nature of lending and borrowing.

The prominence of marketplace lending seems to result almost inevitably in further financialization. While trading volumes of financial investors increase, retail investors can become direct lenders to other private borrowers for the first time and without intermediation or federal insurance. In addition, financial markets are playing an even more central role than ever before. Both trends contribute to the dominance of financial motives and financial markets as the defining themes of financialization.

In the years to come, regulation will play a crucial role in steering the growth of marketplace lending in a productive and sustainable manner. Regulatory bodies, policy-makers and governmental agencies need to investigate and precisely assess the long-term consequences of marketplace lending in the midst of a new wave of financialization. This represents a crucial mission, as millions of borrowers are now directly exposed to financial markets. Hence, this is likely to demand new regulatory instruments. For both policy-makers and executives, it will also be of interest to anticipate which industry might next be subject to some form of disruption, especially since ICT continues to make substantial technological progress.

Within academia, financialization unlocks an entire new field of research with ample opportunities for further study. On a behavioral level, it is important to better understand the effects of marketplace lending on consumer choice and decision-making. In addition, advanced analytics can also contribute better methods for credit risk modeling in order to improve risk management. Furthermore, economists need to evaluate the impact of the resulting financialization on market stability and consider the potential effects of future ICT innovations on the credit business in the 
long run.

\section{Appendix: Expert interviews}

We selected interview partners based on their expertise, availability and accessibility. We have made every effort to include a broad range of views, as well as a cross-industry selection. Although this does not constitute a formal random selection, we are confident that we have assembled a highly relevant and representative panel.

Over a period of 9 months between February and August 2015, we interviewed almost 40 experts individually. Each interview took between 45 and 90 minutes and was subsequently transcribed. We followed the suggested methodology of Schultze and Avital (2011) for the design of interviews in information systems research, specifically employing the appreciative interview technique. We have combined retrospective questions about (i) observations regarding the experiences of interview partners and (ii) their company with conceptual questions regarding the structure and future of the industry (Gideon, 2012; Schultze and Avital, 2011).

We rely foremost on our interviews to identify the ICT trends that have enabled marketplace lending. We thus designed this part of our interview as an open-ended question, i. e. "which developments in ICT, in your opinion, have contributed most to the emergence of marketplace lending in recent years?" The responses were synthesized in the four themes outlined in this paper. However, given the unstructured nature of the responses, we have refrained from aggregating the answers into percentages.

\begin{tabular}{llll}
\hline & Company & Job title & Place of interview \\
\hline 1 & Leading blockchain company & CEO & Money20/20 conference (USA) \\
2 & Venture investment fund & Managing director & Global investor summit (Israel) \\
3 & Israeli FinTech incubator & Founder & Personal interview (Israel) \\
4 & Leading SME marketplace lending plat- & Senior VP international & Money20/20 conference (USA) \\
& form & & \\
5 & European bank & Head of compliance (E. U.) & Phone interview \\
6 & Top 3 U. S. marketplace lender & CEO & Personal interview (USA) \\
7 & FinTech incubator U. K. & Co-founder & Finovate Europe conference (U. K.) \\
8 & Marketplace lending platform & Head of regulatory affairs & Phone interview
\end{tabular}


9 U.S. marketplace lending platform

10 Top 4 U. K. commercial bank

11 U.S. bank, corporate venture fund

12 European SME marketplace lender

13 European universal bank

14

15

16 Top 4 U. K. commercial bank

17 SME industry association

18 Data aggregation service (Eastern Europe)

Data aggregation service (Eastern Europe)

36 Fund of fund information platform

37 Advanced data analytics

U.S. SME marketplace lender

Biometric verification

FinTech-focused investment fund

Data aggregation company

Investment firm

Data provider (API services)

Data aggregation company

U.S. retail bank

FinTech incubator USA

Marketplace lender SME

UK marketplace lender

European FinTech industry association

Corporate venture arm of U.S. bank

FinTech online blog

FinTech-focused VC

Banking data analytics service firm
JIT Special Issue 2016 | Financialization
Chief data officer

Head of digital innovation

Managing director

CEO

Director accelerator program

Investment manager

CEO

Digital director

Manager

CEO

CTO

Money20/20 conference (USA)

Finovate Europe conference (U. K.)

Money20/20 conference (USA)

World Economic Forum, Davos

(Switzerland)

Personal interview at headquarter

(U. K.)

Personal interview at headquarter

World Economic Forum Davos (Switzerland)

Personal interview at headquarter (U.K.)

Finovate Europe conference (U. K.)

MoneyConf industry conference

(Northern Ireland)

MoneyConf industry conference

(Northern Ireland)

Personal interview

Phone interview

Personal interview (USA)

FinTechConnect (London)

Personal interview (USA)

Finnovate conference (London)

Personal interview (U. S. HQ)

Phone interview

Money 20/20 conference (USA)

FinTechConnect (London)

Phone interview

Head of data analytics

Anonymous (non-disclosure

Finovate Europe conference (U. K.)

requested)

Director

Personal interview

Independent

Personal interview (USA)

Investment Director

Personal interview (U. K.)

Director international development

World Economic Forum Davos

(Switzerland)

Phone interview

World Economic Forum (Davos) 


\section{References}

Adams, Z. and T. Glück (2015). "Financialization in commodity markets: A passing trend or the new normal?" Journal of Banking \& Finance 60, 93-111.

Allen, F. and A. M. Santomero (2001). "What do financial intermediaries do?" Journal of Banking \& Finance 25 (2), 271-294.

Alloway, T. and M. Scully (2015). "Wall Street's thinking about creating derivatives on peerto-peer loans.” Bloomberg. URL: http://www . bloomberg. com/news/articles/201504-30/wall-street-s-latest-craze-meets-small-short-in-new-derivatives (visited on 12/22/2015).

Armbrust, M., I. Stoica, M. Zaharia, A. Fox, R. Griffith, A. D. Joseph, R. Katz, A. Konwinski, G. Lee, D. Patterson, and A. Rabkin (2010). “A view of cloud computing.” Communications of the ACM 53 (4), 50-58.

Bain Jr., J. S. (1968). Industrial Organization. 2nd Edition. New York: Wiley.

Bakos, J. Y. (1991). “A strategic analysis of electronic marketplaces.” MIS Quarterly 15 (3), $295-310$.

— (1997). "Reducing buyer search costs: Implications for electronic marketplaces." Management Science 43 (12), 1676-1692.

Bakos, Y., H. C. Lucas, W. Oh, G. Simon, S. Viswanathan, and B. W. Weber (2005). "The impact of e-commerce on competition in the retail brokerage industry." Information Systems Research 16(4), 352-371.

Bank for International Settlements (2001). "Electronic finance: A new perspective and challenges." BIS Papers 7. URL: https: //www.bis.org/publ/bppdf/bi spap07 .htm (visited on $08 / 14 / 2016)$.

Berkeley, A. R. (1997). “Nasdaq's technology floor: Its president takes stock.” IEEE Spectrum $34(2), 66-67$. 
Bhimani, A. (2015). "Exploring big data's strategic consequences.” Journal of Information Technology 30 (1), 66-69.

Black, F. (1971a). “Toward a fully automated stock exchange, part I." Financial Analysts Journal $27(4), 28-35$.

— (1971b). "Toward a fully automated stock exchange, part II." Financial Analysts Journal $27(6), 24-28$.

Bord, V. and J. A. C. Santos (2012). "The rise of the originate-to-distribute model and the role of banks in financial intermediation.” Economic Policy Review 18 (2), 21-34.

Campbell-Kelly, M. and D. D. Garcia-Swartz (2013). "The history of the internet: The missing narratives.” Journal of Information Technology 28 (1), 18-33.

Chordia, T., A. Goyal, B. N. Lehmann, and G. Saar (2013). "High-frequency trading." Journal of Financial Markets 16 (4), 637-645.

Clemons, E. K. and B. W. Weber (1997). "Information technology and screen-based securities trading: Pricing the stock and pricing the trade." Management Science 43 (12), 1693-1708.

Davis, G. F. (2009). Managed by the Markets: How Finance Reshaped America. New York: Oxford University Press.

D’Avolio, G., E. Gildor, and S. Andrei (2001). Technology, Information Production, and Market Efficiency. Harvard Institute of Economic Research, Cambridge, MA.

Dewan, S. and H. Mendelson (2001). "Information technology and trader competition in financial markets: Endogenous liquidity.” Management Science 47 (12), 1581-1587.

Epstein, G. A. (2005). Financialization and the World Economy. Cheltenham, UK and Northampton, MA: Edward Elgar.

Erb, C. B. and C. R. Harvey (2006). "The strategic and tactical value of commodity futures." Financial Analysts Journal 62 (2), 69-97.

Ericsson (2015). Ericsson Mobility Report: On the Pulse of the Networked Society: June 2015. Ed. by P. Cerwall. URL: https : / /www . ericsson . com/res/docs/2015/ericssonmobility-report-june-2015.pdf (visited on 08/24/2016). 
Gideon, L., ed. (2012). Handbook of Survey Methodology for the Social Sciences. New York: Springer.

Gomber, P. and M. Haferkorn (2013). "High-frequency-trading: High-frequency-trading technologies and their implications for electronic securities trading." Business \& Information Systems Engineering 5 (2), 97-99.

Haas, P., I. Blohm, C. Peters, and J. M. Leimeister (2015). “Modularization of crowdfunding services: Designing disruptive innovations in the banking industry.” In: 36th International Conference on Information Systems (ICIS).

Hendershott, T., C. Jones, and A. Menkveld (2011). "Does algorithmic trading improve liquidity?" Journal of Finance 66 (1), 1-33.

Holloway, H. (1989). "Information technology and company policy: Financial transactions: The International Stock Exchange.” Journal of Information Technology 4 (2), 104-107.

Huang, J., E. Makoju, S. Newell, and R. D. Galliers (2003). “Opportunities to learn from 'failure' with electronic commerce: A case study of electronic banking." Journal of Information Technology 18 (1), 17-26.

Huang, R. D. and H. R. Stoll (1996). "Dealer versus auction markets: A paired comparison of execution costs on Nasdaq and the NYSE.” Journal of Financial Economics 41 (3), 313-357.

Jain, P. K. (2005). "Financial market design and the equity premium: Electronic versus floor trading." Journal of Finance 60 (6), 2955-2985.

Jenkins, P. (2016). "US peer-to-peer lending model has parallels with subprime crisis.” $F i$ nancial Times. URL: https : / / www . ft . com/ content/84f696ec-2436-11e6-9d4dc11776a5124d (visited on 09/19/2016).

Jordá, Ò., M. Schularick, and A. M. Taylor (2016). "The great mortgaging: Housing finance, crises, and business cycles." Economic Policy 31 (85), 107-152.

Kaniadakis, A. and P. Constantinides (2014). "Innovating financial information infrastructures: The transition of legacy assets to the securitization market." Journal of the Association for Information Systems 15 (Special Issue), 2014. 
Keim, D. B. and A. Madhavan (1997). "Transactions costs and investment style: An interexchange analysis of institutional equity trades." Journal of Financial Economics 46 (3), $265-292$.

Kim, Y. K. (2013). "Household debt, financialization, and macroeconomic performance in the United States, 1951-2009." Journal of Post Keynesian Economics 35 (4), 675-694.

Krippner, G. R. (2005). “The financialization of the American economy.” Socio-Economic Review 3 (2), 173-208.

Lagoarde-Segot, T. (2016). "Financialization: Towards a new research agenda." International Review of Financial Analysis (in press).

Lechman, E. and A. Marszk (2015). "ICT technologies and financial innovations: The case of exchange traded funds in Brazil, Japan, Mexico, South Korea and the United States." Technological Forecasting and Social Change 99, 355-376.

Lending Club (2015). How has Lending Clubs investor base changed. URL: http: / / kb . lendingclub . com/investor / articles / Investor / How - has - Lending - Club - s investor-base-changed (visited on 09/19/2016).

London Stock Exchange (2015). Regulatory Story: Investment Prospectus: P2P Global Investments PLC. URL: http://www . Iondonstockexchange.com/exchange/news/marketnews/market-news-detail/P2P/12408791.html (visited on 12/21/2015).

Lucas, H. C., W. Oh, and B. W. Weber (2009). "The defensive use of IT in a newly vulnerable market: The New York Stock Exchange, 1980-2007.” Journal of Strategic Information Systems 18(1), 3-15.

Madhavan, A. (1995). "Consolidation, fragmentation, and the disclosure of trading information." Review of Financial Studies 8 (3), 579-603.

Merton, R. C. (1995). "Financial innovation and the management and regulation of financial institutions." Journal of Banking \& Finance 19 (3-4), 461-481.

Morgan Stanley (2015). Global Marketplace Lending: Disruptive Innovation in Financials. 
Noonan, L. and M. Arnold (2015). "Beyond banking: Alternative groups seize business from lenders." Financial Times. URL: https://www.ft.com/content/cbba1ff2-65cf-11e5a28b-50226830d644 (visited on 08/29/2016).

Palley, T. I. (2013). Financialization: The Economics of Finance Capital Domination. London, United Kingdom: Palgrave Macmillan.

Parker, C. and B. W. Weber (2014). "Launching successful e-markets: A broker-level orderrouting analysis of two options exchanges." Journal of Management Information Systems $31(2), 47-76$.

Purnanandam, A. (2011). "Originate-to-distribute model and the subprime mortgage crisis." Review of Financial Studies 24 (6), 1881-1915.

Reck, M. (1998). “The formal and systematic specification of market structures and trading services.” Journal of Management Information Systems 15 (2), 9-21.

Schultze, U. and M. Avital (2011). "Designing interviews to generate rich data for information systems research.” Information and Organization 21 (1), 1-16.

Seddon, J. J.J. M. and W. L. Currie (2016). "A model for unpacking big data analytics in high-frequency trading." Journal of Business Research (in press).

Stein, J. C. (2010). "Securitization, shadow banking \& financial fragility." Daedalus 139(4), $41-51$.

Stockhammer, E. (2010). Financialization and the global economy. URL: http://www . peri . umass . edu/fileadmin/pdf/working_papers/working_papers_201-250/WP240. pdf (visited on 08/28/2016).

Stoll, H. R. (2006). "Electronic trading in stock markets.” Journal of Economic Perspectives $20(1), 153-174$.

Tang, K. and W. Xiong (2010). Index Investment and Financialization of Commodities. Cambridge, MA. URL: http: //www . nber .org/papers/w16385 (visited on 08/28/2016).

Tett, G. (2015). “The sharing economy is now a playground for Wall Street." Financial Times. URL: https : / / www .ft . com/ content/62f2737e-6210-11e5-9846-de406ccb37f2 (visited on 12/21/2015). 
Tufano, P. (2003). “Financial Innovation.” In: Handbook of the Economics and Finance. Ed. by G. M. Constantinides, M. Harris, and R. M. Stulz. Vol. 1. Amsterdam, Netherlands: Elsevier, pp. 307-335.

van der Zwan, N. (2014). “Making sense of financialization.” Socio-Economic Review 12(1), 99-129.

Venters, W. and E. A. Whitley (2012). “A critical review of cloud computing: Researching desires and realities.” Journal of Information Technology 27 (3), 179-197.

Weber, B. W. (2006). “Adoption of electronic trading at the International Securities Exchange." Decision Support Systems 41 (4), 728-746.

Woerner, S. L. and B. H. Wixom (2015). "Big data: Extending the business strategy toolbox." Journal of Information Technology 30 (1), 60-62.

Zhang, X. and L. Zhang (2015). "How does the internet affect the financial market? An equilibrium model of internet-facilitated feedback trading." Management Information Systems Quarterly 39(1), 17-37. 